\title{
Contesting the EU, Contesting Democracy and Rule of Law in Europe. Conceptual Suggestions for Future Research
}

\author{
Luca Tomini and Seda Gürkan
}

\section{INTRODUCTION}

Over the past several years, a number of EU member states as well as some candidate states have experienced political transformations in a direction opposite to that of democratisation. In most of these cases, this phenomenon has been accompanied by the progressive detachment of these countries from the political, administrative and normative influence of the European Union (EU) and/or by a more overt and growing contestation over the EU or its policies. While these developments amounted to the EU's 'autocracy crisis' (Kelemen 2019, p. 35), multiple crises that hit the Union since 2009-ranging from the financial crisis and Brexit to the refugee crisis-limited the EU's ability to deal with these instances of autocratisation, that is, a political change towards

\section{Tomini $(\bowtie) \cdot S$. Gürkan}

Université libre de Bruxelles, Brussels, Belgium

e-mail: ltomini@ulb.ac.be

S. Gürkan

e-mail: sgurkan@ulb.ac.be

(C) The Author(s) 2021

A. Lorenz and L. H. Anders (eds.), Illiberal Trends and Anti-EU Politics in East Central Europe, Palgrave Studies in European Union Politics, https://doi.org/10.1007/978-3-030-54674-8_12 
autocracy, in and around the EU. And when the EU intervened to defend democracy and the rule of law in member states or candidates, this intervention into domestic affairs was met with a new form of contestation over the EU altering these countries' relationships with the EU.

These developments have led many scholars to question the puzzle of turning authoritarian while being a member or a candidate of the EU (Müller 2013) or to analyse the inherent problems related to the EU's instruments to address post-accession non-compliance (Sedelmeier 2014; Szente 2017). These studies have implicitly assumed that autocratisation and turning away from the EU are interconnected. However, the relationship between these two processes has largely remained understudied. Although it is well-known that both the contestation over the EU and autocratisation are multi-causal in nature, there is ample empirical evidence to suspect the existence of a causal relationship between the two as they occur simultaneously not only in acceding countries (Turkey being probably the most notable example) or potential candidates in the Western Balkans (Serbia under President Vučić) but also in some member states such as Hungary or Poland. Against this background, this chapter explores and questions this possible interaction and causal link between these two processes in times of a supposed declining quality of democracy in Europe.

It is argued that the profound crisis of fundamental values of the EU in and around the EU can only be grasped by studying two distinct but closely interconnected phenomena. The first process is 'autocratisation', which refers to the political changes that move countries towards autocracy. The second process is 'de-Europeanisation', which refers to the progressive detachment of some countries from the political, administrative and normative influence of the Union. Although these two phenomena occur simultaneously, they remain distinct and mutually impact on each other. Autocratisation is closely related to the internal dynamics of member states, and autocrats' domestic preferences, whereas de-Europeanisation refers to the changing relationship of a state with the EU, and it is largely about member state governments' response to the EU's impact in national politics. While autocratisation helps us to understand governments' declining commitment to the EU's values and norms, de-Europeanisation explains autocrats' changing attitudes to the European integration. It is the contention of this chapter that conceptual clarification between autocratisation and de-Europeanisation provides a 
powerful explanation of why autocratic leaders in Hungary, Poland or Turkey contest the EU more and more.

In order to substantiate these arguments, in this chapter we first shed light on the distinction between autocratisation and de-Europeanisation by discussing both concepts, presenting their origin and tracing their development in the relevant scholarly literature. We then, secondly, discuss the type of relationship existing between the two and, in the final section, we discuss the theoretical and policy implications of these findings.

\section{Autocratisation in Central AND EASTERN EUROPE}

The analysis of the politics of East Central European countries clearly shows the shift that has taken place within democratisation studies in recent years, from the traditional perspective focused on the challenges of democratic transition and consolidation to the current focus on the opposite phenomena of autocratisation.

These different phenomena can be causally interrelated, as various studies in the literature demonstrate (Tomini 2015; Bánkuti et al. 2012; Ágh 2016): paths of problematic democratic consolidation are reliable indicators of the likelihood of an autocratisation process. Nonetheless, although connected, these processes remain distinct, and it is clear that in the current debate, the question is no longer 'What are the causes of the difficult democratic consolidation?' in some of the countries of East Central Europe, but rather and more explicitly, 'What are the reasons and the modalities of the beginning of the authoritarian turn?'.

The event that unquestionably changed the political and scholarly debate, as far as East Central Europe is concerned, was without any doubt the landslide victory of Fidesz in Hungary in 2010 and the birth of the second Orbán government, along with the constitutional and legislative transformations that followed in the subsequent years (Kornai 2015; Ágh 2016; Buzogány 2017) and with the influence that the Hungarian transformations had on other countries in the region and even beyond. Since that time, Hungary, and later other EU member states (Poland, above all, see Przybylski 2018) have become explicit examples of autocratisation, in addition to cases already studied in other regions of the world, such as Venezuela, or Thailand, among others. 
There are multiple reasons to adopt the concept of autocratisation in order to define these processes of political change in an authoritarian direction. Even before moving on to the analysis of causes, modalities, actors and paths, it is necessary to address the ontological question of the very nature of the phenomenon under examination.

When it comes to analysing the phenomena opposed to democratisation, the literature is full of conceptual proposals: democratic breakdown, regression, collapse, backsliding, deterioration or demise, erosion, dedemocratisation, loss of democratic quality and even more. The list is long (see Cassani and Tomini 2018), and the flourishing of often contradictory concepts is a good indicator of recent interest in this type of phenomenon. In this fragmented context, the use of the concept of autocratisation, which makes the exercise of political power more arbitrary and repressive and that restricts the space for public contestation and political participation in the process of government selection (Cassani and Tomini 2018), provides significant advantages.

First of all, it is a comprehensive concept that allows us to categorise, within the same framework, different phenomena brought together by the same direction of change (i.e. autocracy). Mirroring democratisation as a process of 'moving towards this not entirely fixed future (democratic) state' (Whitehead 2002, p. 3), autocratisation as a process of change can begin within very different political regimes (democratic and nondemocratic $^{1}$ ) and end in the same way with the installation of different types of regimes in an ideal continuum ranging from liberal democracy to defective democracy, to electoral autocracy up to a closed autocracy. In this framework, processes of change that transform a country from liberal democracy to defective democracy, although different in many respects, can be compared and assessed against more radical transformations such as, for example, the transition between a defective democracy to a closed autocracy. This advantage is particularly useful in the case of East Central European countries, which historically have been the subject of exercises of comparison (both internal and with other regions). Therefore,

${ }^{1}$ Although it may seem counterintuitive that a process of autocratisation may also concern a non-democratic regime, this in reality can take place, for example, in the transition from a so-called electoral autocracy to a closed autocracy in which the dimension related to political participation is further limited or suppressed, for example, through the tout court elimination of elections (as in military coups) or through manipulations such as the illegal extension of term limits that eliminate de facto the possibility for citizens to choose their representatives. 
the possibility of using the same concept to analyse phenomena, albeit of different intensity, in Hungary, Serbia, Russia, Poland and even Turkey, must be considered as an added value.

Secondly, as defined above, it is a concept ready for empirical analysis. The presence of a negative change within one of the three constitutive dimensions (participation, contestation and executive limitation) is sufficient to identify a potential case of autocratisation. As a comprehensive concept, autocratisation is broad enough to capture developments-such as the attacks on independent media or to civil society organisations, as well as limitation to the political opposition-that go beyond the narrow erosion of rule of law. Furthermore, the extent of the change is easily assessed by examining which of the dimensions are involved in the process. A change from liberal democracy to defective democracy essentially concerns the dimension of executive limitation, in relation to the erosion of the boundaries within which an incumbent ruler exercises the political authority. In a different way, a change from defective democracy to closed autocracy also ends up involving the dimensions of contestation (the presence of a free and fair electoral process and the possibility of criticising and replacing the government in office) and participation (the capacity and possibility of citizens to actually choose the government of the country allowed by the guarantee of political rights).

Thirdly, the concept of autocratisation clarifies a certain normative ambiguity that characterises concepts such as democratic backsliding, regression or de-democratisation, which are defined in a negative way, as the loss of something positive (democracy), or as a backwards movement. In most cases, these processes do not restore previous regimes. Take, as an example, the case of Hungary: the process of change implemented by Fidesz does not constitute a backsliding or a regression towards something that existed in the past, but instead represents the creation of something new-a different type of regime.

Fourthly, the conceptualisation of autocratisation as a 'regime change' constitutes an explicit methodological and theoretical choice in favour of a case-oriented approach in which the selection and classification of the cases is made through a qualitative approach and each potential case of autocratisation is examined in-depth. This choice has the disadvantage of discarding political transformations that might represent a shift towards autocracy but do not amount to an outright change in the formal and informal institutions regulating how political power is assigned and exercised. On the other hand, this allows us to focus the analysis on real 
cases of autocratisation, eliminating possible false positives. It is therefore a more selective approach that allows a more in-depth investigation of the selected cases, in which minor changes (which do not produce a change of regime, but only a change within the regime) are interpreted as warning signs of a process of autocratisation that may or may not occur. This approach is particularly useful, especially in the case of Central and Eastern Europe characterised by frequent institutional and political changes (e.g. the instability of the party systems of the region, the rise and fall of populist parties and leaders), because it separates the wheat (the real cases of autocratisation intended as a change of regime) from the chaff (the cases of political change to be interpreted in another sense, such as democratic performance deficit, see Fukuyama 2015, or deconsolidation phenomena, see Foa and Mounk 2016, including growing disaffection towards the elite).

The ongoing debate on the 'rule of law crisis' or 'autocracy crisis' in Central and Eastern Europe is, in its essential nature, a debate on the EU's foundational values in which the stake is the contestation of a normative conception of liberal democracy based on participation, competition and rule of law intended as a guarantee of citizen protection against the state and as a balance and control between constitutional powers. The debate does not take place merely for academic reasons: it depends on the fact that, since the beginning of the twenty-first century, some governments of EU member states have embarked (for the reasons and causes that have been analysed in this volume) in a path of institutional, legislative and political change that moves them away from the values and founding principles of liberal democracy as understood above, and which can be effectively summarised with the concept of autocratisation.

\section{De-Europeanisation in Contemporary Europe}

While autocratisation helps us to capture the changes related to both the exercise of political power and the spheres of public contestation and political participation, a more recent concept-namely, the deEuropeanisation process - sheds light on a new kind of contestation over the EU. Although most scholars defined this concept as the 'reversal of the reform process' or the 'divergence from the EU norms and prescribed models' (Yilmaz 2016; Wódka 2017), from a more sociologically sensitive perspective, we suggest conceptualising de-Europeanisation as a broader and deeper process, whereby de-Europeanisation takes place 
not only in relation to a specific policy field or at the level of the recipient government and institutions but in the politics and society at large. This broader phenomenon is manifested in the form of a growing indifference or scepticism' in the society or among the political elite towards the EU (Aydın-Düzgit and Kaliber 2016, p. 6). In this understanding, deEuropeanisation includes not only the reversal of the reform process, but also those instances where reform is incurred without the need or even obligation to attain alignment with the EU, or where actors deliberately refrain from referring to the $\mathrm{EU}$ in justification of the reforms undertaken' (Aydın-Düzgit and Kaliber 2016, p. 6; Onursal-Beşgül 2016). In other words, the EU ceases to have an influence on a given state because the nature of the relationship between the EU and state/society switches from a mutual engagement to a disengagement. Against this backdrop, we define de-Europeanisation as a process of mutual or unilateral disengagement between the EU and national level whereby normative reference to the EU and the EU's political influence become increasingly irrelevant in the logics of domestic politics, formal and informal institutions, and public policy choices.

This definition has the following advantages. Firstly, by transcending the conceptualisation of de-Europeanisation as a mere backsliding in the reform process, the definition provides conceptual clarification. While scholars used autocratisation and de-Europeanisation interchangeably, our suggested conceptualisation highlights the distinction between deEuropeanisation and autocratisation, which, we argue, remain distinct processes. De-Europeanisation involves the changes in the relationship of the EU with the state or a given society, whereas autocratisation concerns changes in the relationship between the state and the society.

Secondly, de-Europeanisation understood as the reversal of the reform process might be easily confused with the terms used in the classical Europeanisation literature. In this respect, Radaelli's typology, ${ }^{2}$ which includes four different degrees for the measurement of the impact of the EU, might equally capture the idea of the reversal of the reform process through inertia or retrenchment (Radaelli 2003, pp. 37-38). ${ }^{3}$

\footnotetext{
2 Radaelli's typology draws on Börzel (1999) and Cowles et al. (2001). On the question of measurement of Europeanisation, see also Börzel and Risse (2007).

${ }^{3}$ These outcomes of Europeanisation include inertia, absorption, transformation and retrenchment (Radaelli 2003, pp. 37-38). Absorption refers to change as adaptation, which implies a low degree of changes without real change or transformation in the logic
} 
Inertia happens in cases where the EU-level policies diverge from national ones, and there is a considerable resistance to adopt EU rules or policies (no change). Retrenchment refers to a paradoxical effect implying that national policies become less Europeanised than before (reversal). Whereas, in our conceptualisation, de-Europeanisation does not only encompass a mere backsliding in the reform process, but also a broader and deeper process of detachment from the EU affecting the society and state level. In other words, while retrenchment implies a negative change in policy, polity and/or politics, our conceptualisation of deEuropeanisation includes also the erosion of the normative attractiveness of the EU as a reference point for the political elite and among the society at large.

Thirdly, our suggested definition refers to a disengagement between the EU and the national level. Therefore, it can be applied to different empirical realities, including member states, candidate countries or states involved in the EU neighbourhood policy, with only one prerequisite: that the process takes place where previously there was some form of Europeanisation. It would not make sense to talk about disengagement if there had not been a process of progressive approach and mutual influence between the two levels before.

Fourthly, according to this definition, the de-Europeanisation process may take place in one or all of the three classic dimensions in which the impact of the EU on the national sphere unfolds: politics, policies and polities. In this perspective, de-Europeanisation may regard the process of reform of public policies, the institutional dimension, but also the normative and value-related dimension, thus integrating institutionalist and sociological approaches into a single analytical framework. Finally, our suggested definition conceptualises de-Europeanisation as a process (instead of an outcome). In this way, the definition shifts attention from the negative impacts (outcome) of the mutual disengagement at national level to a more incremental change in the relationship between the EU and state/society levels.

In accordance with our suggested definition, we expect to observe deEuropeanisation at two levels: as a result of a change either at the EU-state level or at the EU-society level, or at both levels. At the EU-state level, de-Europeanisation might take the form of the EU's disengagement from

of political behaviour. Transformation, on the other hand, indicates a fundamental or substantial change in the logic of political behaviour. 
domestic politics, and/or a retreat of a state from the EU. As for the EUsociety level, de-Europeanisation is expected to occur when support to the EU decreases in the society, and the society overwhelmingly turns away from the EU. For the purposes of the analytical focus of this chapter, we devote particular attention to the cases where the state deliberately turns away from the EU and its normative influence. In these cases, where the state (either a member or a candidate) disengages from the institutional structure of the EU or even contests the EU, we theorise that the main indicator of de-Europeanisation at the EU-state level is the political elite's declining commitment to the EU, and this is manifested in the form of a lack of or negative reference to the EU in the political elite's discourse. On the basis of these theoretical insights, and in the light of recent developments in Central and Eastern Europe, an essential question that needs to be answered is the relationship between these separate but supposedly interlinked phenomena: Does autocratisation trigger de-Europeanisation at the EU-state level or does distancing from the EU bear an impact on a given country's autocratisation process? In other words, what is the relationship between these two phenomena?

\section{The Link Between De-Europeanisation and Autocratisation: The Primacy of Domestic Politics as the Driver of De-Europeanisation}

Since de-Europeanisation and autocratisation are different processes, there may be situations in which there is de-Europeanisation in the absence of a process of autocratisation. The most relevant example is perhaps that of the UK after the Brexit referendum. In this country, deEuropeanisation unfolds as a result of the choice made by British citizens in the 2016 referendum on the permanence of the UK in the European Union. The unilateral disengagement of the UK from the EU will probably result in the weakening of EU normative reference and political influence on UK domestic politics, policies and polity. At the same time, as de-Europeanisation unfolds, at the moment there are no empirical signs of forms of autocratisation, in the direction of reduced opportunities for public contestation, political participation and the erosion of the mechanisms of executive limitations. 
On the other hand, empirical evidence shows that there are situations in which a process of autocratisation unfolds without a concomitant deEuropeanisation process. Serbia under Prime Minister Vučić is a good example of this occurrence, where a process of autocratisation is not accompanied by a disengagement between the EU and the national level. Several studies have shown how Serbia under Vucić's government has embarked on a process of autocratisation (Castaldo and Pinna 2018; Kapidzic 2020). At the same time, the government repeatedly restated its formal commitment to European accession and integration, although this approach has been considered instrumental to cover the ongoing autocratisation process. And thus, de-Europeanisation and autocratisation seem in no way mutually necessary to the other. There are cases of deEuropeanised countries that do not show evident signs of autocratisation, as well as cases of autocratisation without tangible signs of departure from the commitment to join, or remain part of the EU.

However, there is a third option, which is the most interesting for the purposes of understanding the puzzle of turning autocratic while being a member or a candidate of the EU: that the two processes occur relatively in the same span of time. By way of example, the cases of Hungary and Turkey are representative of the combined presence of these two phenomena. Despite the differences, both cases show a process of autocratisation. In the case of Hungary, this happens through a weakening of accountability and checks to executive power, while in the case of Turkey, through a reduction of civil and political rights, and the accountability of the executive. Both countries also show a de-Europeanisation process; in the case of Hungary, through a detachment mainly related to the dimension of some public policies and European values, while in the case of Turkey, through a gradual phasing-out of the perspective of membership, a detachment from European values and normative influence, and a hostile discourse of the government vis-à-vis the EU.

In these specific situations, in which we observe both processes in action, the question should be "What type of connection is there between de-Europeanisation and autocratisation?'. Post-enlargement and post2008 financial crisis Central and Eastern Europe is the ideal laboratory to examine the connection between the two phenomena, and to overturn the mainstream perspective of Europeanisation studies that focuses, in a more or less explicit way, on the EU as a starting point for any explanation of domestic changes. 
The numerous empirical cases available in the region show that the 'autocracy crisis' experienced by the European Union in the last years has primarily domestic causes. Numerous studies show the mainly domestic origins of Viktor Orbán's rise to power and of his anti-liberal political project (see Buzogány 2017 among others). The same home-made roots can be found in the explanation of the AKP's rule and Erdogan's authoritarian turn in Turkey (Somer 2016); regarding the political crises related to the corruption scandals in Romania and the institutional tensions between president and government (Iusmen 2015); in the authoritarian turn of Vučić in Serbia (Castaldo and Pinna 2018); in the attempts to put the judiciary under the control of the executive in Poland by the government led by PiS (Przybylski 2018); or further back in the past, in Vladimír Mečiar's authoritarian attempt in Slovakia in the late 1990s (Haughton 2003). These are phenomena that are distinct in scope and outcome, but similar for the mostly domestic origin of the causes. One more thing that is also similar, and which often leads to confusion in the analysis of these processes, is the context in which these domestic changes took and continue to take place; that is, the context of a process of European integration and of an increasing role of the EU in the domestic politics of these countries. However, the argument here is that the fact that these phenomena occur in the context of a growing role of the EU in national policies does not necessarily mean that the cause of them is somehow related to, or originated from the EU.

Autocratisation, in this perspective, logically and empirically precedes de-Europeanisation. As a consequence, the relationship with the EU (and the EU's impact on these countries) is shaped as a function of leaders' interests to pursue an authoritarian turn. This is the substantial difference: de-Europeanisation is not the result of a retrenchment or an inertia in the face of a stimulus, but it may be the consequence of endogenous processes within national political systems (such as autocratisation) which, only in the second step, has implications for the state's relationship with the EU. In other words, when the two phenomena occur together in a given state, the nature of the European Union's relationship with that state is not the cause of domestic level changes (the EU is not the explanatory variable). But the reaction or eventual inaction of the EU to the autocratisation contributes (among other factors) to define the outcome and the path of the process of domestic autocratisation (hence the EU is an intervening factor). And in this perspective, it should be emphasised that the EU's crisis decade (Brack and Gürkan 2020) has arguably limited its ability to 
respond to these authoritarian transformations, further aggravating their magnitude.

The EU intervenes in the cost and benefit calculation of domestic actors willing to turn authoritarian for domestic reasons, who have therefore already developed a normative preference antithetical to liberal democracy. In many cases, the more the political elite follow an authoritarian path, the more these countries' relations with the EU deteriorates because complying with the EU normative requirements in terms of democracy and rule of law becomes too costly for their project of authoritarian transformation. Hence, these worsening relations are also accompanied by a more hostile discourse of the ruling elite on the EU, especially when (and if) the European Union takes initiatives or measures to counter these domestic authoritarian turns, as shown by Hungary, Poland and Turkey. In these cases, the EU's reaction to authoritarian transformation may also become a tool in the hands of national actors and leaders who use it defensively to further strengthen their discourse, legitimising further authoritarian choices in the name of the defence of national interest and/or sovereignty.

\section{Conclusions}

The main contention of this chapter was twofold: firstly, it argued that autocratisation and de-Europeanisation remain two distinct processes, although in most of the empirical cases, they occur together and affect each other. Secondly, the recent phenomenon of contesting the EU and its values can only be grasped through a closer examination of the internal dynamics of a given state. Even in the case of a member state, a case where a state's legal and institutional system is closely integrated to the $\mathrm{EU}$, the autocratisation occurs mainly because of domestic dynamics and is driven by domestic (autocratic) agents. However, once the autocratisation process starts taking place, turning against the EU or contesting its normative influence becomes the preferred option for autocrats as maintaining a value-based relationship with the EU becomes a highly costly option for autocratic leaders.

These observations on the puzzle of contestation over the EU in and around Europe have theoretical, methodological and policy implications. Firstly, these findings provide theoretical insights into the de-Europeanisation research agenda. Theoretically, the analysis of the 
de-Europeanisation phenomenon needs to shift attention from EUlevel explanations to domestic level actors because the driver of the de-Europeanisation process is ultimately the domestic political elite. Secondly, any study that aspires to analyse the phenomena of contestation over the EU or its values should carefully integrate in its explanatory framework two analytically separate phenomena (autocratisation and deEuropeanisation) as well as various levels that simultaneously interact with each other (international, EU as well as domestic levels).

Thirdly, these observations, in turn, have methodological implications. In the light of our main argument which suggests that domestic actors remain essential in driving the de-Europeanisation agendas of authoritarian states, the analysis of distancing from the EU in contemporary Europe needs to devote a particular attention to domestic agents. In order to explain autocrats' hostile attitude vis-à-vis the EU, carefully designed small-N comparative studies or single case studies need to trace separately both phenomena (autocratisation and de-Europeanisation), and bring in qualitative methods, such as discourse analysis or process-tracing.

Turning to the policy implications, as autocrats' declining commitment to the EU is mainly shaped and driven by their domestic agenda, the EU's ability to intervene in autocrats' cost and benefit calculus remains limited. And in cases where the EU criticises autocratisation in member states or candidates, this is usually backfired by autocratisation agents. As observed in the cases of Turkey or Hungary, EU's negative evaluations of autocratisation in those countries usually nurture a more nationalistic discourse by the political elite and an anti-European backlash in the society. Therefore, unless the EU can offer new incentives that will persuasively engage autocrats into a more democratic path, the EU's ability to mitigate the autocratisation process will be marginal. In other words, while restoring a firm political conditionality based on close monitoring, clear conditions and credible incentives appear to be the main panacea for deviating the autocratisation process in candidates. In addition, a similar post-accession compliance monitoring mechanism backed by incentives (or the withdrawal of incentives) remains essential for changing the incentive structure of autocratic leaders in member states.

\section{REFERENCES}

Ágh, Attila. 2016. The Decline of Democracy in East-Central Europe: Hungary as the Worst-case Scenario. Problems of Post-Communism 63 (5-6): 277-287. 
Aydın-Düzgit, S., and A. Kaliber. 2016. Encounters with Europe in an Era of Domestic and International Turmoil: Is Turkey a De-Europeanising Candidate Country? South European Society and Politics 21 (1): 1-14.

Bánkuti, M., G. Halmai, and K.L. Scheppele. 2012. Hungary's Illiberal Turn: Disabling the Constitution. Journal of Democracy 23 (3): 138-146.

Börzel, Tanja A. 1999. Towards Convergence in Europe? Institutional Adaptation to Europeanization in Germany and Spain. Journal of Common Market Studies 39 (4): 573-596.

Börzel, T.A., and T. Risse. 2007. Europeanization: The Domestic Impact of EU Politics. In Handbook of European Union Politics, ed. K.E. Jorgensen, M.A. Pollack, and B.J. Rosamond, 482-504. London: Sage.

Brack, Nathalie, and S. Gürkan. 2020. Theorizing the Crises of the European Union. London: Routledge.

Buzogány, Aron. 2017. Illiberal Democracy in Hungary: Authoritarian Diffusion or Domestic Causation? Democratization 24 (7): 1307-1325.

Cassani, A., and L. Tomini. 2018. Reversing Regimes and Concepts: From Democratization to Autocratization. European Political Science. 1-16. https://doi.org/10.1057/s41304-018-0168-5.

Castaldo, A., and A. Pinna. 2018. De-Europeanization in the Balkans. Media Freedom in post-Milošević Serbia. European Politics and Society 19(3): 264281.

Cowles, M.G., J. Caporaso, and T. Risse (eds.). 2001. Transforming Europe: Europeanization and Domestic Change. Ithaca: Cornell University Press.

Foa, R.S., and Y. Mounk. 2016. The Danger of Deconsolidation: The Democratic Disconnect. Journal of Democracy 27 (3): 5-17.

Fukuyama, Francis. 2015. Why Is Democracy Performing so Poorly? Journal of Democracy 26 (1): 11-20.

Haughton, Tim. 2003. Facilitator and Impeder: The Institutional Framework of Slovak Politics During the Premiership of Vladimír Mečiar. The Slavonic and East European Review 81: 267-290.

Iusmen, Ingi. 2015. EU Leverage and Democratic Backsliding in Central and Eastern Europe: The Case of Romania. Journal of Common Market Studies 53 (3): 593-608.

Kapidžić, Damir. 2020. The Rise of Illiberal Politics in Southeast Europe. Southeast European and Black Sea Studies 20 (1): 1-17.

Kelemen, R. Daniel. 2019. Federalism and European Integration. In European Integration Theory, ed. A. Wiener, T.A. Börzel, and T. Risse, 27-42. Oxford: Oxford University Press.

Kornai, János. 2015. Hungary's U-turn: Retreating from Democracy. Journal of Democracy 26 (3): 34-48.

Müller, Jan-Werner. 2013. Defending Democracy Within the EU. Journal of Democracy 24 (2): 138-149. 
Onursal-Beşgül, Özge. 2016. Policy Transfer and Discursive De-Europeanisation: Higher Education from Bologna to Turkey. South European Society and Politics 21 (1): 91-103.

Przybylski, Wojciech. 2018. Explaining Eastern Europe: Can Poland's Backsliding Be Stopped? Journal of Democracy 29 (3): 52-64.

Radaelli, Claudio M. 2003. The Europeanization of Public Policy. In The Politics of Europeanization, ed. K. Featherstone and C.M. Radaelli, 27-56. Oxford: Oxford University Press.

Sedelmeier, Ulrich. 2014. Anchoring Democracy from Above? The European Union and Democratic Backsliding in Hungary and Romania After Accession. Journal of Common Market Studies 52 (1): 105-121.

Somer, Murat. 2016. Understanding Turkey's Democratic Breakdown: Old vs. New and Indigenous vs. Global Authoritarianism. Southeast European and Black Sea Studies 16 (4): 481-503.

Szente, Zoltán. 2017. Challenging the Basic Values. The Problems of the Rule of Law in Hungary and the Failure of the European Union to Tackle Them. In The Enforcement of EU Law and Values. Ensuring Member States' Compliance, ed. A. Jakab and D. Kochenov, 456-475. Oxford: Oxford University Press.

Tomini, Luca. 2015. Democratizing Central and Eastern Europe: Successes and Failures of the European Union. London and New York: Routledge.

Whitehead, Laurence. 2002. Democratization: Theory and Experience. Oxford: Oxford University Press on Demand.

Wódka, Jakub. 2017. Institutional Aspects of the (De-)Europeanization of Turkish Political Parties. The Case of the Justice and Development Party (AKP) and the Republican People's Party (CHP). Journal of Balkan and Near Eastern Studies 19 (2): 153-170.

Yilmaz, Gözde. 2016. From Europeanization to De-Europeanization: The Europeanization Process of Turkey in 1999-2014. Journal of Contemporary European Studies 24 (1): 86-100. 
Open Access This chapter is licensed under the terms of the Creative Commons Attribution 4.0 International License (http://creativecommons.org/licenses/ by $/ 4.0 /$ ), which permits use, sharing, adaptation, distribution and reproduction in any medium or format, as long as you give appropriate credit to the original author(s) and the source, provide a link to the Creative Commons license and indicate if changes were made.

The images or other third party material in this chapter are included in the chapter's Creative Commons license, unless indicated otherwise in a credit line to the material. If material is not included in the chapter's Creative Commons license and your intended use is not permitted by statutory regulation or exceeds the permitted use, you will need to obtain permission directly from the copyright holder.

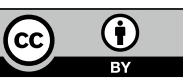

